\title{
Ground-Water Age and Flow at Great Sand Dunes National Monument, South-Central Colorado
}

\author{
By Michael G. Rupert and L. Niel Plummer
}

Great Sand Dunes National Monument (hereinafter called Great Sand Dunes) is located in south-central Colorado along the eastern edge of the San Luis Valley (fig. 1). The San Luis Valley is bounded by the Sangre de Cristo Mountains to the east and the San Juan Mountains to the west. Great Sand Dunes has an altitude ranging from about 7,500 to 10,300 feet and receives annual average precipitation of about 11 inches near the Great Sand Dunes Headquarters (fig. 2).

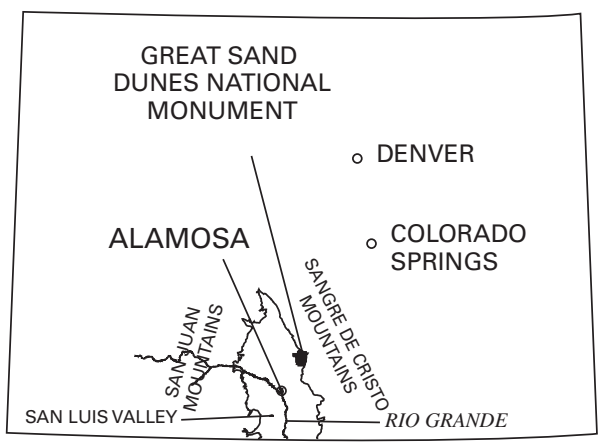

Figure 1. Location of the Great Sand Dunes National Monument, south-central Colorado.

The predominant feature in Great Sand Dunes is the 30 square-mile main dune field (fig. 2) which rises up to 750 feet above the valley floor. The age of the dunes is estimated to be between 2,000 and 12,000 years old (Chatman and others, 1997). Composition of the sand indicates the predominant source is the San Juan Mountains to the west. The sand was transported to the San Luis Valley by the Rio Grande and other local streams and then carried by prevailing southwesterly winds to the Sangre de Cristo Mountain front. The shape of the Sangre de Cristo Mountains acts as a sand trap (Chatman and others, 1997).

\section{The Sand Dunes Need Water}

As incongruous as it might seem, existence of the sand dunes is dependent on water (Chatman and others, 1997). Two streams flowing from the Sangre de Cristo Mountains, Medano Creek on the east and southeastern edge, and Sand Creek on the northwestern edge (fig. 2), transport the sand southwestward around the perimeter of the dunes and deposit the sand on the upwind side, where prevailing winds transport the sand north- eastward toward the Sangre de Cristo Mountains again. The rate of sand transport northeastward by wind generally is the same as the rate of sand transport southwestward by water; together, the two mechanisms maintain the dune field in a state of quasiequilibrium (Chatman and others, 1997). Streamflows typically are largest during spring snowmelt, which corresponds with the period of greatest sand transport by the creeks.

An important ecological feature of Great Sand Dunes are wetlands associated with interdunal ponds and depressions that nearly intersect the water table near the western edge of the dune field. The interdunal ponds and depressions provide important habitat for a variety of species that depend on a wetland habitat in an otherwise desert environment. The interdunal ponds are of special concern because their numbers have decreased markedly in recent years. The relatively sudden disappearance of ponds appears to indicate a considerable change in Great Sand Dunes hydrology. The existence and natural maintenance of the dune field and the interdunal ponds are dependent on maintaining ground-water levels at historic elevations.

\section{Two Aquifers Exist at Great Sand Dunes National Monument}

A shallow aquifer and a deep aquifer are the two principal aquifers at Great Sand Dunes. All the water in Medano and Sand Creeks, except what is lost to evapotranspiration, infiltrates into the ground to recharge the shallow aquifer. The shallow and deep aquifers are separated by an impermeable layer of clay about 8 feet thick. Wells V and Y, located near the western edge of Great Sand Dunes (fig. 2), intercept the clay layer about 300 feet below the land surface. It is not known if the deep aquifer extends eastward all the way to the Sangre de Cristo Mountain front.

\section{How Old is Water in the Shallow Aquifer?}

Ground water in the shallow aquifer is much younger than ground water in the deep aquifer (Rupert and Plummer, 2004). Water first seeps down to the shallow aquifer from Medano and Sand Creek (fig. 2). Ground water near Medano and Sand Creeks probably is only a few years old. The ground water then travels in a southwesterly direction, underneath the main dune field. Additional water from precipitation on the dune field moves down to and mixes with the ground water underneath the main dune field. Ground water in the shallow aquifer also travels to springs that discharge to Big and Little Spring Creeks on the west side of 


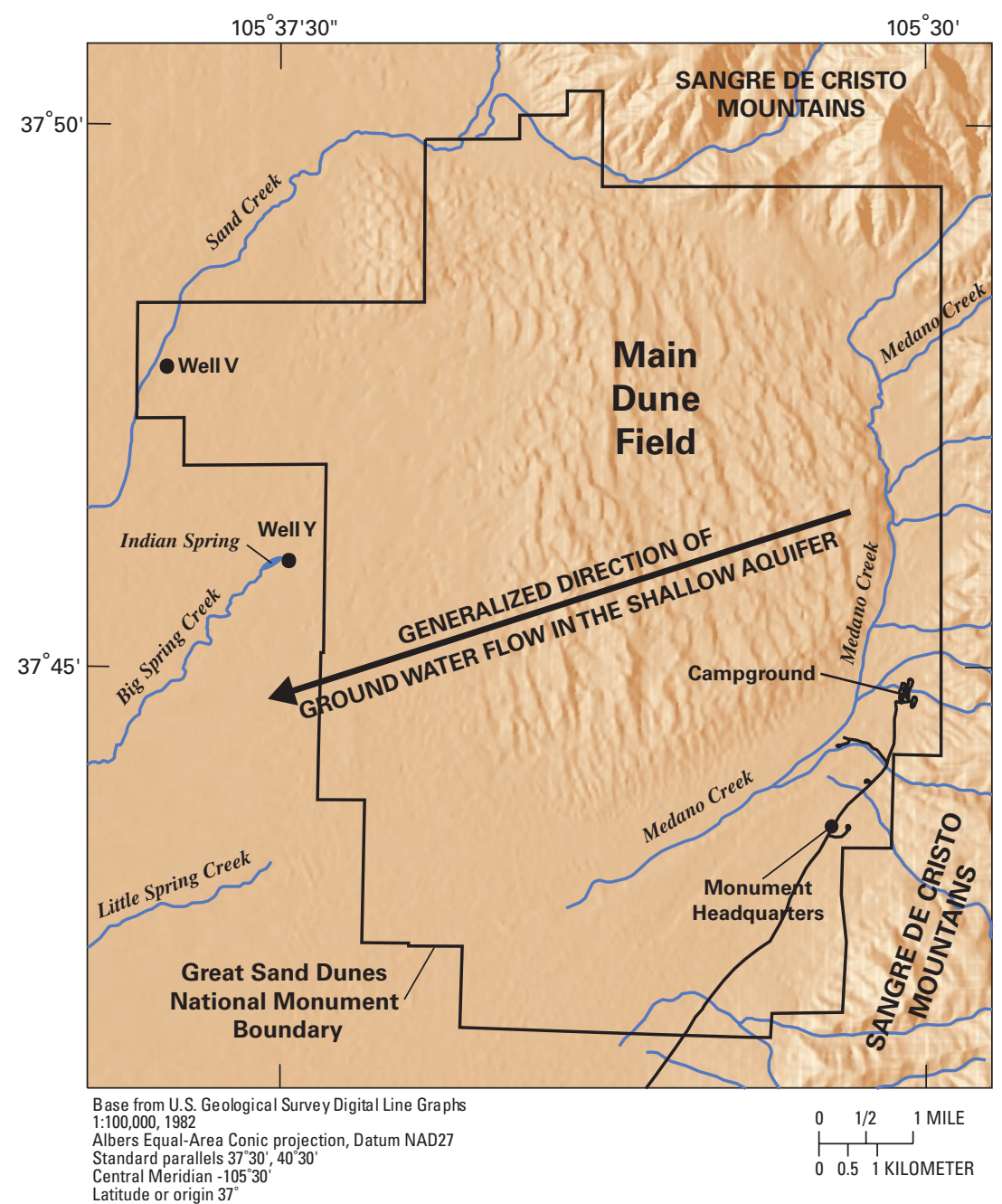

Figure 2. Shaded relief map of the Great Sand Dunes National Monument, south-central Colorado.

Great Sand Dunes. Ground-water age dating using chlorofluorocarbons $\left(\right.$ Freon $^{\mathrm{TM}}$ ) and tritium (an isotope of hydrogen) indicate that it takes more than 60 years for ground water to travel underneath the dune field from Medano and Sand Creeks to Big and Little Spring Creeks (Rupert and Plummer, 2004).

\section{How Old is Water in the Deep Aquifer?}

Using carbon-14 geochemical dating methods, the age of ground water sampled from well $\mathrm{Y}$, which is completed in the deep aquifer and is near the western edge of the dune field (fig. 2), is about 30,000 years before present (plus or minus 3,000 years) (Rupert and Plummer, 2004). This age was determined using methods similar to those used to date charcoal found in firepits of archeological sites. The last major ice advance (Wisconsin) during the ice age peaked about 20,000 years before present (U.S. Geological Survey, 1992); ground water from the deep aquifer is older than that.

\section{References}

Chatman, M., Sharrow, D., and Valdez, A., 1997, Water resources management plan, Great Sand Dunes National Monument, Colorado: National Park Service, Water Resources Division, 197 p.

Rupert, M.G., and Plummer, L.N., 2004, Ground-water flow direction, water quality, recharge sources, and age, Great Sand Dunes National Monument and Preserve, south-central Colorado, 2000-2001: U.S. Geological Survey Scientific Investigations Report 2004-5027, 32 p.

U.S. Geological Survey, 1992, The great ice age: U.S. Geological Survey General Interest Publication, ISBN 0-16-036025-0, 8 p. Accessed May 29, 2002, at URL http://pubs.usgs.gov/gip/ice_age/ 